\title{
MED24 Gene
}

National Cancer Institute

\section{Source}

National Cancer Institute. MED24 Gene. NCI Thesaurus. Code C20712.

This gene plays a role in the transcriptional activation of Sp1. 